\title{
Human salivary cystatin $\mathbf{S}$
}

\section{Cloning, sequence analysis, hybridization in situ and immunocytochemistry}

\author{
Libuse A. BOBEK,* Alfredo AGUIRRE and Michael J. LEVINE \\ Department of Oral Biology, School of Dental Medicine, State University of New York at Buffalo, Buffalo, NY 14214, U.S.A.
}

\begin{abstract}
A human submandibular-gland (SMG) cDNA library was constructed in a $\lambda$ gt11 Sfi-Not orientation-specific expression vector and then screened with antibody generated against human salivary cystatins. The clone C4-4 encoded an $N$ terminally truncated cystatin S, whereas the others encoded cystatin SN. The library was then rescreened with the C4-4, and the inserts of several positive clones were directly amplified from the eluted plaques by linear PCR and the PCR products analysed by Southern blotting and direct DNA sequencing. Two clones (C3 and C12) encoded a full-length secreted cystatin $\mathrm{S}$ and its leader peptide and included 5'- and 3'-untranslated regions. These clones showed a high degree of sequence similarity to cDNA clones encoding human salivary cystatin SN and genomic clones encoding cystatin SN and SA. Hybridization in situ of normal human SMG and parotid-gland (PG) tissue sections localized the cystatin-gene transcripts to the cytoplasm of serous acinar cells of both glands, with a much higher concentration of cystatin mRNA in the SMG. Immunocytochemistry localized the salivary cystatin gene products also to the serous cells, and the levels of cystatin protein correlated with the amount of cystatin mRNA, with a much stronger signal in the SMG than in the PG.
\end{abstract}

\section{INTRODUCTION}

Cystatins are potent inhibitors of cysteine proteinases such as ficin, papain and cathepsins B, H and L (Anastasi et al., 1983; Abrahamson et al., 1986; Barrett et al., 1986b). Despite their structural diversity, this physiological function is common to all the members of the cystatin superfamily, suggesting that they are derived from a common ancestor (Muller-Esterl et al., 1986; Saitoh et al., 1988). Recently, Rawlings \& Barrett (1990) constructed a scheme for the evolution of the diverse group of proteins that show sequence identity with chicken cystatin. Data from the comparison of amino acid sequences were supplemented with other evidence, such as the occurrence of disulphide bonds, the numbers of internal sequence repeats in the molecules and biological function. As a result, they suggested that additional families be recognized to accommodate the proteins that are not included in the previously established cystatin families 1,2 and 3 (Barrett et al., 1986a,b). For example, rice cystatin, which appears to be intermediate between family 1 and 2, might be assigned to a fourth family, whereas histidine-rich glycoprotein and $\alpha_{2}$ HS-glycoprotein might be members of new families; however, they point out that no data are available regarding the last two proteins as cysteine-proteinase inhibitors.

Human saliva contains multiple forms of cystatins which belong to family 2 of the cystatin superfamily. These were first isolated as cysteine-containing phosphoproteins by Shomers et al. $(1982 a)$. Isemura et al. $(1984 a, 1986,1987)$ determined the amino acid sequence of cystatin S (then named SAP-1), cystatin SN (neutral pI) and cystatin SA (acidic pI) isolated from human whole saliva. Each protein contained 113 amino acids and showed $90 \%$ sequence identity with the other two salivary cystatins. These cystatins had about $54 \%$ sequence identity with cystatin $\mathrm{C}$, which also belongs to family 2 , but is found in high amounts in cerebrospinal fluid and urine (Grubb \& Lofberg, 1982; Brzin et al., 1984; Ghiso et al., 1986). It was suggested that the cystatins originally characterized from whole saliva were degraded by aminopeptidases, since later on cystatins $\mathrm{S}$ (Hawke et al., 1987; Saitoh et al., 1988) and SN (Al-Hashimi et al., 1988) with an additional eight residues at the $N$-terminus (total of 121 residues) were isolated from glandular saliva. Genes encoding cystatins SN and SA have been cloned and sequenced (Saitoh et al., 1987). They are composed of three exons and two introns, and one gene spans about $4.0 \mathrm{kbp}$ of the genomic DNA. The proteins deduced from the coding sequences comprise a secretory signal peptide of 20 amino acids, followed by a secreted peptide of 121 amino acids. A cDNA clone, 594 bp long, encoding a fulllength cystatin SN (then termed SA-I) was isolated and sequenced by Al-Hashimi et al. (1988). Saitoh et al. (1988) isolated and sequenced a truncated cDNA clone encoding 50 amino acid residues from the $C$-terminus of salivary cystatin, which is identical with the cystatin $S$ sequence, except that amino acid residue 115 is asparagine rather than aspartic acid. The decoded sequence was also identical with the corresponding portion of cystatin SA, except at amino acid position 101, where glutamine replaced glutamic acid.

Although much attention has been given to the physiological functions and inhibitory mechanisms of cystatins, the precise structural requirements for these activities remain to be determined. A possible mode of interaction of chicken egg-white cystatin with papain has been proposed in which three parts of the inhibitor (the $N$-terminus and two hairpin loops containing residues 53-57 and 102-107) are important for the inhibition of

Abbreviations used : SMG, submandibular gland; PG, parotid gland; ds, double-stranded; ss, single-stranded; dd, dideoxy; PBS, phosphate-buffered saline [10 mM-sodium phosphate buffer (pH 7.2)/154 mM-NaCl]; TBS, Tris-buffered saline (10 mM-Tris/HCl/154 mM-NaCl, $\mathrm{pH} 8.0)$; TE, $10 \mathrm{mM}-$ Tris/HCl (pH 8.0)/1 mM-EDTA; $2 \times$ SSC, 300 mM-NaCl/30 mM-sodium citrate; $1 \times$ Denhardt's, $0.01 \%$ BSA $/ 0.01 \%$ polyvinylpyrrolidone $/ 0.01 \%$ ficoll; DTT, dithiothreitol; poly(A) ${ }^{+}$, polyadenylated; LPCR, linear PCR.

* To whom reprint requests should be addressed.

The nucleotide sequence of the cDNA encoding cystatin $S$ reported in this paper has been submitted to the EMBL, GenBank and DDBJ Nucleotide Sequence Databases under the accession number X54667.

Vol. 278 
papain (Bode et al., 1988). Studies on the structure-function relationships of salivary cystatins will be greatly facilitated by the availability of cDNA clones encoding the salivary cystatins. Accordingly, the present study describes the isolation and analysis of cDNA clones encoding human salivary cystatin $\mathrm{S}$ and $\mathrm{SN}$ from a submandibular-gland (SMG) cDNA expression library. In addition, we have examined the relative level and location of cystatin-gene transcripts in normal human salivary glands by in situ hybridization and have localized salivary cystatin-gene protein products by immunocytochemistry. The information obtained on patterns of cystatin-gene expression in normal human tissues should provide a basis for further studies on the pathogenesis of salivary-gland neoplasia.

\section{MATERIALS AND METHODS}

\section{Materials}

The following were purchased from Promega (Madison, WI, U.S.A.): RiboClone cDNA Synthesis System Kit, Packagene Lambda DNA Packaging System, Protoblot $\lambda$ gt 11 Immunoscreening System containing secondary antibody (goat antirabbit IgG), alkaline phosphatase conjugate and the necessary colour-development substrates (Nitroblue Tetrazolium and 5bromo-4-chloroindol-3-yl phosphate), Nitroplus 2000 hybridization membrane, Escherichia coli strains Y1090 and JM109, $\lambda$ gt11 Sfi-Not and pGem-11Zf vectors, $\lambda$ forward and reverse primers, RNasin, and all restriction and other DNA-modifying enzymes. Genious Nonradioactive DNA Labeling and Detection Kit was from Boehringer-Mannheim Biochemicals (Indianapolis, IN, U.S.A.). Sequenase kit was from United States Biochemicals (Cleveland, OH, U.S.A.), Geneclean kit from Bio 101 (La Jolla, CA, U.S.A.). All radioisotopes were from New England Nuclear Corp. (Boston, MA, U.S.A.). A normal swine serum, biotinylated swine anti-rabbit IgG and avidin-biotin-alkaline phosphatase complex were from Dako, Glostrup, Denmark. Oligo(dT)cellulose, naphthol AS-MX phosphate (free acid) and Fast-Red TR salt were from Sigma Chemical Co. (St. Louis, MO, U.S.A.). A temperature cycler was obtained from COY (Ann Arbor, MI, U.S.A.).

\section{Human salivary-gland tissue}

Normal SMG tissue was obtained after prophylactic radical neck dissection from a 72-year-old male afflicted with a nasopharyngeal carcinoma. Parotid tissue was obtained from a patient with a history of chronic inflammatory disease of the lateral neck. Informed consent was obtained from patients before surgery. Immediately after excision, specimens were stored in liquid $\mathrm{N}_{2}$ until used.

\section{Construction of an SMG cDNA library}

RiboClone cDNA Synthesis System Kit was used for the synthesis of the double-stranded (ds) cDNA. Protocols described by Promega and Sambrook et al. (1989) were followed. Total SMG RNA was isolated from $1.0 \mathrm{~g}$ of tissue by extraction with guanidine isothiocyanate followed by centrifugation in a $\mathrm{CsCl}$ gradient. Poly(A) ${ }^{+}$RNA was selected by affinity chromatography on an oligo(dT)-cellulose column. The $\lambda$ gt11 Sfi-Not expression vector was used as a cloning vehicle. Directional cloning was achieved with a unique oligodeoxynucleotide primer-adaptor containing the recognition site for NotI upstream from an oligo $(\mathrm{dT})_{15}$ sequence which primed the first-strand synthesis. EcoRI adaptors were added to the double-stranded cDNA, which was followed by digestion with NotI and ligation of the cDNA to the EcoRI-NotI dephosphorylated $\lambda$ gtll Sfi-Not vector arms. Ligated DNA was packaged into the Packagene
Lambda DNA Packaging System. The titre of the library was determined on the Y1090 host strain (Young \& Davis, 1983) to be $6 \times 10^{6}$ independent clones. One half of this library was amplified on the Y1090 host (Sambrook et al., 1989) and the other half was left unamplified for the direct library screening.

\section{Selection and analysis of cDNA clones encoding salivary cystatins}

Screening of library with anti-cystatin antibody. The SMG cDNA expression library was plated on to a Y1090 bacterial host at a density of 10000 plaques $/ 90 \mathrm{~mm}$ plate. Cystatin clones were identified by using a rabbit polyclonal antibody (whole rabbit serum) to human salivary cystatin (Shomers et al. 1982) and the Protoblot Immunoscreening System, following the manufacturer's instructions. Several positive clones were purified by additional rounds of screening.

Screening of library with C4-4 probe and amplification of cDNA inserts by linear PCR (LPCR). An insert of cDNA clone, designated C4-4, which encodes the 5'-terminally truncated cystatin $\mathbf{S}$ (see the Results section) was used as a hybridization probe for selection of additional cystatin clones. DNA was labelled by random priming using the Genious Nonradioactive DNA Labeling and Detection Kit. Positive plaques were eluted, and aliquots of the eluted plaques were used directly for amplification in vitro by LPCR using a DNA thermocycler (Smith et al., 1990). A typical reaction mixture contained $10 \mu \mathrm{l}$ of eluted plaque (template DNA), $10 \mu \mathrm{l}$ of $10 \times \mathrm{Taq}$ DNA polymerase buffer $[500 \mathrm{~mm}-\mathrm{KCl} / 100 \mathrm{~mm}-\mathrm{Tris} / \mathrm{HCl}(\mathrm{pH} \mathrm{9.0)/}$ $15 \mathrm{~mm}-\mathrm{MgCl}_{2} / 0.1 \%$ gelatin $/ 1.0 \%$ Triton $\mathrm{X}-100$ ], $4 \mu \mathrm{l}$ of a $2.5 \mathrm{mM}$ mix of all four dNTPs ( $0.1 \mathrm{~mm}$ final concn.), $1 \mu \mathrm{l}$ each of the $\lambda$ forward and reverse primer ( $77 \mathrm{ng}), 0.5 \mu \mathrm{l}$ ( 2.5 units) of Taq DNA polymerase and distilled water to a final volume of $100 \mu \mathrm{l}$. The reaction mixture was overlaid with $100 \mu \mathrm{l}$ of mineral oil. In all, 30 cycles of amplification were performed at a denaturation temperature of $94^{\circ} \mathrm{C}$ for $1 \mathrm{~min}$, an annealing temperature of $52^{\circ} \mathrm{C}$ for $2 \mathrm{~min}$ and an extension temperature of $72{ }^{\circ} \mathrm{C}$ for $2 \mathrm{~min}$.

DNA sequence analysis. Cystatin inserts of antibody-positive clones were first subcloned either in the M13 (Messing, 1983) and/or pGem11 vectors. For sequencing in M13, the $\lambda$ cDNA clones were first cut with the NotI enzyme and the resulting cohesive ends were blunt-ended before cutting with the second enzyme, EcoRI. The cDNA insert fragments were then subcloned into the EcoRI/SmaI sites of the M13 mp18 and mp19 vectors. For sequencing in the pGem, the clones were digested with the $S f i \mathrm{I}$ and NotI enzymes and the cDNA inserts were subcloned into the SfiI/NotI sites of the pGem-11Zf $(+)$ vector. The nucleotide sequences were determined by the dideoxynucleotide-chain-termination method of Sanger et al. (1977) using the Sequenase kit and $\left[\alpha^{-{ }^{35}}\right.$ S $]$ dATP. With PCR amplified DNA, direct sequencing was employed utilizing also the Sequenase kit and the $\lambda$ forward and reverse primers, which were first labelled with $\left[\gamma^{32} \mathrm{P}\right] \mathrm{ATP}$ and polynucleotide kinase. The PCR-amplified DNA was gel-purified in order to remove the excess primers and the dNTPs, and then further purified with a Geneclean kit. The labelling, annealing and sequencing reactions were performed as described by Kusukawa et al. (1990), with some modifications. To the annealed mix of the primer and DNA template, $1 \mu \mathrm{l}$ of $100 \mathrm{mM}$-DTT, $1 \mu \mathrm{l}$ of manganese buffer (100 mM- $\mathrm{MnCl}_{2} / 150 \mathrm{~mm}$ citric acid, $\mathrm{pH} \mathrm{7.0)}$ and $0.5 \mu \mathrm{l}$ of doubledistilled water were added. After mixing, $3.5 \mu \mathrm{l}$ of the mixture were added to each of the four termination mixes $(2.5 \mu \mathrm{l})$ in which the dNTPs/ddNTPs ratio was increased from $80: 8$ (found in the kit) to $240: 8$.

DNA sequence management. The University of Wisconsin Genetics Computer Group software was used to manage the 
DNA sequence information (Devereux et al., 1984). For DNA alignment, the GAP program was used (Needleman \& Wunsh, 1970).

\section{Hybridization in situ}

Preparation of probes for hybridization in situ. The pGem$11 \mathrm{Zf}(+)$ plasmid vector containing the cDNA clone C4-4 was used as the template. The plasmid DNA was first linearized to produce 'run-off' transcripts derived from the insert sequence only, and the linearized DNA was phenol-extracted and ethanolprecipitated. For generation of the anti-sense RNA probe, about $250 \mathrm{ng}$ of plasmid were linearized with SfiI and the SP6 RNA polymerase was used for transcription, following the protocols described by Promega. For the negative control probe (RNA sense strand), the same amount of plasmid was linearized with NotI, and the T7 RNA polymerase was used for transcription. Typically, the transcription reactions contained linearized plasmid DNA ( $250 \mathrm{ng}$ ), $4.0 \mu \mathrm{l}$ of $5 \times$ transcription buffer [ $200 \mathrm{mM}$ Tris $/ \mathrm{HCl}$ (pH 7.5) $30 \mathrm{~mm}-\mathrm{MgCl}_{2} / 10 \mathrm{~mm}$-spermidine $/ 50 \mathrm{~mm}$ $\mathrm{NaCl}$ ], $2.0 \mu \mathrm{l}$ of $100 \mathrm{~mm}$-DTT, $4.0 \mu \mathrm{l}$ of $2.5 \mathrm{~mm}$ each of ATP, CTP and GTP, $8.0 \mu 1$ of $\left[\alpha_{-}{ }^{35}\right.$ S $]$ UTP (sp. radioactivity $1350 \mathrm{Ci} /$ mmol), $1 \mu \mathrm{l}$ of RNasin (25 units) and $1 \mu \mathrm{l}$ (10 units) of SP6 or T7 RNA polymerase. The reaction was allowed to proceed for $60 \mathrm{~min}$ at $37^{\circ} \mathrm{C}$.

Preparation of tissue sections for hybridization in situ. Frozen sections ( $6 \mu \mathrm{m}$ thick) from parotid and submandibular glands were obtained at $-20^{\circ} \mathrm{C}$. To reduce experimental variability, adjacent serial sections of parotid and submandibular tissues were prepared on single slides. Sections were then air-dried, fixed in $4 \%$ paraformaldehyde, washed in PBS, dehydrated in graded alcohols, and stored at $-20^{\circ} \mathrm{C}$ until use for hybridization in situ (within 1 week).

Prehybridization treatment of tissue sections. Tissue slides were soaked in $0.2 \mathrm{M}-\mathrm{HCl}$ for $20 \mathrm{~min}$ at room temperature, rinsed in water for $5 \mathrm{~min}$, soaked in $2 \times \mathrm{SSC}$ for $10 \mathrm{~min}$ at room temperature, and then heated in $0.1 \times \mathrm{SSC}$ at $60^{\circ} \mathrm{C}$ for $10 \mathrm{~min}$. Next, the slides were treated for 10 min with Pronase $(250 \mu \mathrm{g} / \mathrm{ml}$ in $50 \mathrm{~mm}$-Tris/HCl, pH 7.5, containing 5 mM- $\mathrm{Na}_{2}$ EDTA), after which the slides were rinsed for $1 \mathrm{~min}$ in glycine $(2 \mathrm{mg} / \mathrm{ml})$ in PBS. Slides were then rinsed twice for $1 \mathrm{~min}$ in PBS, followed by post-fixation in freshly prepared $4 \%$ paraformaldehyde for $20 \mathrm{~min}$ and block fixation for $5 \mathrm{~min}$ in $3 \times$ PBS. The slides were rinsed twice for $5 \mathrm{~min}$ in PBS and then treated with $0.25 \%$ acetic anhydride in $100 \mathrm{~mm}$-triethanolamine, $\mathrm{pH} 8.0$, for $10 \mathrm{~min}$ to block polar and charged groups on tissue sections. Finally, the slides were rinsed four times in PBS for $5 \mathrm{~min}$ each and then dehydrated through $30,60,80,95$ and $100 \%$ ethanol for $5 \mathrm{~min}$ each at room temperature.

Hybridization and washes. The slides were hybridized with $50 \mu \mathrm{l}$ of hybridization mixture [50\% deionized formamide/ $1 \times$ Denhardt's/300mm-NaCl/5mM-EDTA/20mM-Tris $/ \mathrm{HCl}$ (pH 8.0)/100 mM-DTT/tRNA $(50 \mu \mathrm{g} / \mathrm{ml})]$ containing $\sim 1 \times$ $10^{6}$ c.p.m. at $42^{\circ} \mathrm{C}$ overnight in a tray with pre-warmed mineral oil. After rinsing in chloroform three times for $5 \mathrm{~min}$ each (in coplin jars with coverslips on), the slides were drained and air-dried. This was followed by washing with $4 \times$ SSC at room temperature three times for $5 \mathrm{~min}$ each (coverslips removed). Next, the slides were treated with RNAase A $(20 \mu \mathrm{g} / \mathrm{ml})$ in $500 \mathrm{~mm}-\mathrm{NaCl} / 10 \mathrm{~mm}$-Tris/ $\mathrm{HCl}, \mathrm{pH} 8.0$, for $1 \mathrm{~h}$ at $37^{\circ} \mathrm{C}$ and then washed in the same buffer without RNAase for $30 \mathrm{~min}$ at $37^{\circ} \mathrm{C}$. This was followed by washing the slides in 2 litres of $2 \times \mathrm{SSC}$ at $45^{\circ} \mathrm{C}$ for $30 \mathrm{~min}$ (with stirring) and in $0.1 \times \mathrm{SSC}$ for $45 \mathrm{~min}$. Last, the slides were dehydrated sequentially in 70 and $90 \%$ ethanol/0.3 $\mathrm{M}$-ammonium acetate for $10 \mathrm{~min}$ each and then air-dried.

Emulsion coating and developing of slides. Liquid-emulsion autoradiography was performed with Kodak NTB-2 emulsion diluted $1: 1$ with water at $4{ }^{\circ} \mathrm{C}$ for 10 days. The slides were then processed with Kodak D-19 developer. The slides were then dehydrated sequentially with 70 and $90 \%$ ethanol/0.3 Mammonium acetate for $5 \mathrm{~min}$ each, air-dried and stained with Harris hematoxylin and eosin $\mathrm{Y}$.

\section{Immunocytochemistry}

Salivary-gland tissues were fixed for $10 \mathrm{~h}$ in $10 \%$ buffered formalin and then paraffin-embedded. Sections $(5 \mu \mathrm{m})$ were then de-paraffinized, hydrated and rinsed in TBS, $\mathrm{pH} 7.2$, and then incubated with normal swine serum $(1: 5, \mathrm{v} / \mathrm{v})$ for $20 \mathrm{~min}$. The sections were next incubated with rabbit anti-salivary cystatin $(1: 200, \mathrm{v} / \mathrm{v})$ for $30 \mathrm{~min}$ at room temperature in a humidified atmosphere. After the primary-antibody incubation and a TBS wash, slides were incubated for 30 min with a biotinylated swine anti-rabbit IgG $(1: 500, \mathrm{v} / \mathrm{v})$. After another TBS wash, slides were incubated for $30 \mathrm{~min}$ with avidin-biotin-alkaline phosphatase prepared according to the manufacturers' directions. After a TBS wash, the chromogenic substrate solution (naphthol AS-MX phosphate and Fast-Red TR salt containing levamisole to block endogenous alkaline phosphatase activity) was added. Sections were counterstained with Mayer's hematoxylin. Negative controls consisted of replacing the primary antibody with non-immune rabbit serum $(1: 200, \mathrm{v} / \mathrm{v})$.

\section{RESULTS}

\section{Construction of the SMG CDNA library and selection and analysis of cDNA clones encoding salivary cystatins}

In order to utilize both the nucleic acid and antibody probes for the library screening, $\lambda$ gt11 Sfi-Not expression vector was used. Since this vector is also designed for orientation-specific cDNA cloning, this method doubles the in-frame orientation for the expression of inserts over conventional random-orientation cloning and thus increases the possibility of isolating specific cDNA using antibody probes. Screening of about 30000 recombinant clones from both the unamplified and amplified human SMG cDNA library with the anti-cystatin antibody revealed that about $1 \%$ reacted positively. Nine positive clones were plaquepurified by additional rounds of screening and analysed further. Phage recombinant DNA was isolated from liquid minicultures of infected Y1090 (Sambrook et al., 1989), digested with EcoRI/

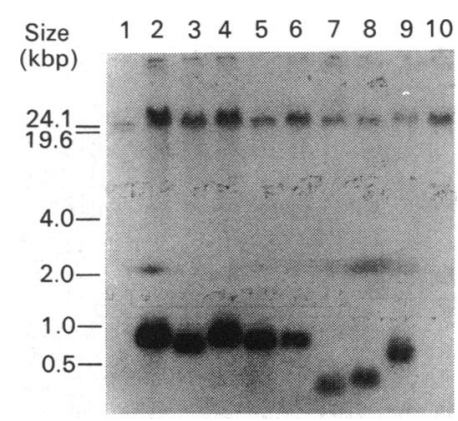

Fig. 1. Southern-blot analysis of CDNA clones which were identified as positive with anti-cystatin antibody

DNA was digested with EcoRI/NotI restriction enzymes, fragments separated on a $1.4 \%$-agarose gel, transferred on to a Nitroplus 2000 hybridization membrane and hybridized to the insert of cDNA clone C4-1 (lane 4). Lanes represent the following clones: lane 1, $\mathrm{Cl}-2$; lane 2, C1-1; lane 3, C1-3; lane 4, C4-1; lane 5, C4-3a; lane 6, C4-3b; lane 7, C4-2; lane 8, C4-4; lane 9, C4-5a; lane 10, C4-5b. 


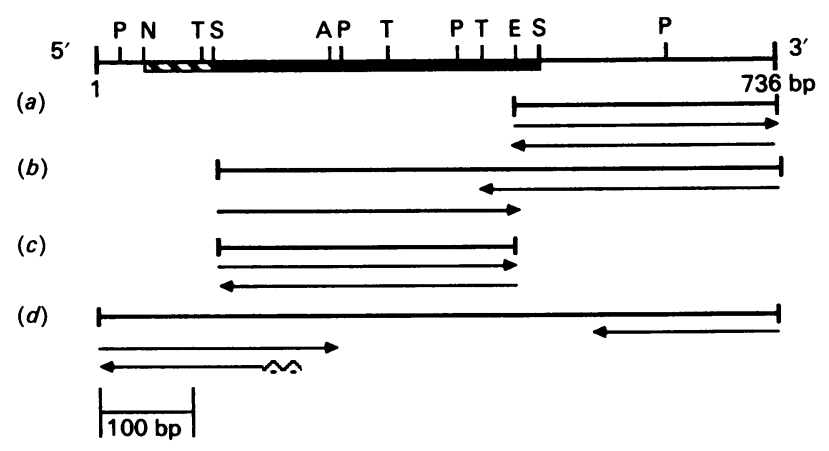

Fig. 2. Restriction-enzyme map of clone $\mathrm{C} 3$ and DNA sequence strategy for clones $\mathrm{C} 3$ and $\mathrm{C4}-4$

Key to restriction enzymes: A, AhaII; E, EcoRI ; $N, N c o I$; No, NotI ; P, PstI; S, StyI; Sf, SfiI ; T, TaqI. The thin lines in the top diagram represent the $5^{\prime}$ - and $3^{\prime}$-untranslated regions; the hatched bar, the putative signal peptide; the thick solid line, the secreted protein. The cDNA clone C4-4 subcloned in M13 mp18 and mp19 as the EcoRI-NotI fragment is represented in $(a)$, as the Sfil-NotI fragment in pGem-11Zf $(+)$ in $(b)$ and as the $S f i \mathrm{I} / E c o$ RI fragment in pGem$11 \mathrm{Zf}(+)$ in $(c)$. The PCR-amplified insert of clone C3 is represented in $(d)$. Arrows indicate the direction and extension of sequencing $\sim$ in $(d)$ represents an internal cystatin SN primer.

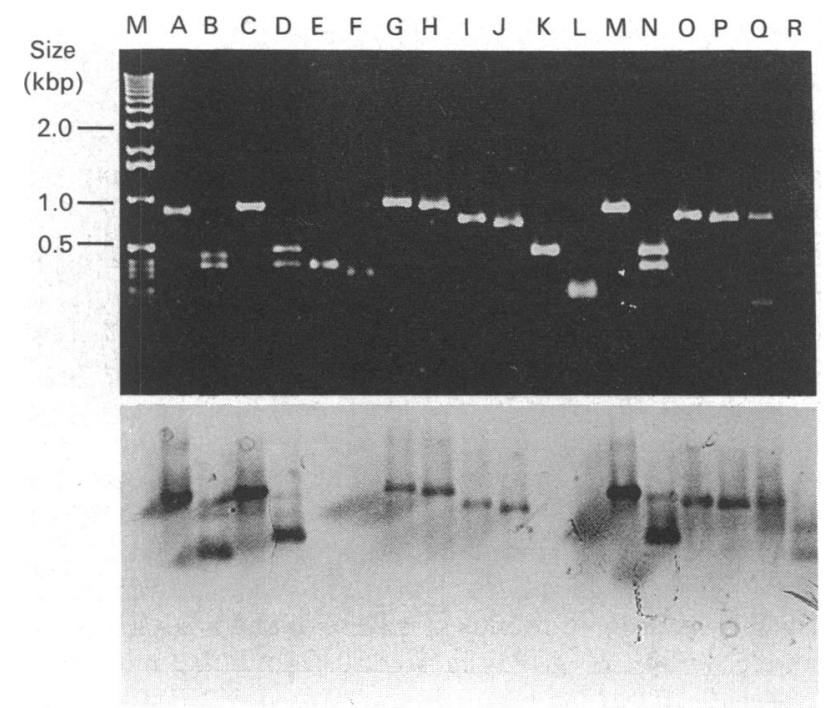

Fig. 3. Agarose-gel and Southern-blot analysis of PCR amplified inserts of cDNA clones selected with insert of clone C4-4

Undigested (lanes A, C, E, G, I, K, M, O and Q) and EcoRI-digested DNA (lanes, B, D, F, H, J, L, N, P and R) was separated by agarosegel electrophoresis, stained with EtBr (top) and transferred to a Nitroplus 2000 hybridization membrane and probed with a $S f i \mathrm{I}-$ EcoRI (5'-end) fragment of clone C4-4 (bottom). Lanes represent the following clones: lanes A and B, C4-4; lanes C and D, C3; lanes $\mathrm{E}$ and $\mathrm{F}, \mathrm{C} 4$; lanes $\mathrm{G}$ and $\mathrm{H}, \mathrm{C} 5$; lanes $\mathrm{I}$ and $\mathrm{J}, \mathrm{C} 7$; lanes $\mathrm{K}$ and $\mathrm{L}$, $\mathrm{Cl0}$; lanes $\mathrm{M}$ and $\mathrm{N}, \mathrm{Cl2}$; lanes $\mathrm{O}$ and $\mathrm{P}, \mathrm{Cl6}$; and lanes $\mathrm{Q}$ and $\mathrm{R}$, C17.

NotI restriction enzymes and analysed by Southern blotting using one of the longest inserts (C4-1) as a hybridization probe (Fig. 1). This probe cross-hybridized with seven of the nine clones identified. Owing to the extensive antibody and nucleic acid cross-reactivity among the isoforms of salivary cystatins, a partial DNA sequence analysis was performed to determine which cystatins were encoded by these antibody-positive clones. Six clones encoded cystatin SN, indicating that the mRNA encoding cystatin $\mathrm{SN}$ is much more abundant in the SMG than
1 GGCTCTCACCCTCCTCTCCTGCAGCTCCAGCTCTGTGCTĆTGCCTCTGAG 50 1111111111111111111111111111111111111111111111111111

1 GGCTCTCACCCTCCTCTCCTGCAGCTCCAGCTTTGTGCTCTGCCTCTGAG 50

MetAlaArgProLeuCysThrLeuLeuLeuLeuMetAlaThrLe 1 GAGACCATGGCCCGGCCTCTGTGTACCCTGCTACTCCTGATGGCTACCCT 100 1 GAGACCATGGCCCAGCATCTGAGTACCCTGCTGCTCCTGCTGGCCACCCT 100 MetAlagloHLsLeuSerThrLeuLeuLeuLeuLeuAlaThrLeu -11 .

AlaGlyAlaLLuAlaserSerSerLysGiugluAsnArgilleIleProGily 101 GGCTGGGGCTCTGGCCTCGAGCTCCAAGGAGGAGAATAGGATAATCCCAG 150 11111111111111111111111111111111111111111 101 AGCTGTGGCCCTGGCCTGGAGCCCCAAGGAGGAGGATAGGATAATCCCGG 150 AlaValAlaLeuAla IroSerRreLysGluGluAspArgIleIleProgly

GlyIleTyrAspalaAspLeuAsnAspGiluTrRValGinargAlaLeu 151 GTGGCATCTATGATGCAGACCTCAATGATGAGTGGGTACAGCGTGCCCTT 200 11111111111 1 1111111111111111111111111111111111 51 GTGGCATCTATAACGCAGACCTCAATGATGAGTGGGTACAGCGTGCCCTT 200 GlyIleTyrAsnAlaAspLeuAsnAspGluTrpValGInArgAlaLeu

30 40

H1sPheAlaIleSerGluTyrAsnLysAlaThrGluAspGluTyrTyrArg 201 CACTTCGCCATCAGCGAGTACAACAAGGCCACCGAAGATGAGTACTACAG 250 11111111111111111111111111111111111111111111111 201 CACTTCGCCATCAGCGAGTATAACAAGGCCACCAAAGATGACTACTACAG 250 H1sPheAlaIleSerGluTyrAsnLysAla ThrLysAspAspTyrTyrArg

ArgProLeuGlnValLeuArgAlaArgGiuglnThrPheGlyGlyValAs 251 ACGCCCGCTGCAGGTGCTGCGAGCCAGGGAGCAGACCTTTGGGGGGGTGA 300 1111111111111111111111111 111111 111111111111 251 ACGTCCGCTGCGGGTACTAAGAGCCAGGCAACAGACCGTTGGGGGGGTGA 300 ArgProLeuArgValLeuArgAlaArgGlnGlnThrValGlyGlyValAsn

TyrPhePheAspValGluvalGlyArgThrIleCysThrLysSerGin 301 ATTACTTCTTCGACGTAGAGGTGGGCCGCACCATATGTACCAAGTCCCAG 350 350 TyrPhePheAspValGluValGlyArgThrIleCysThrLysSerGln

ProAsnLeuAspThrCysAiaPheH1sGluGlnProGluLeuGlnLysLys 351 CCCAACTTGGACACCTGTGCCTTCCATGAACAGCCAGAACTGCAGAAGAA 400

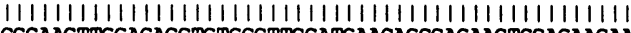
351 CCCAACTTGGACACCTGTGCCTTCCATGAACAGCCAGAACTGCAGAAGAA 400 ProAsnLeuAspThrCysAlaPheH1sGluGInProGluLeuGlnLysLys

GlnLeuCysSerPheGluIleTyrGluvalProTrpgluAspArgMetser 401 ACAGTTATGCTCTTTCGAGATCTACGAAGTTCCCTGGGAGGACAGAATGT 450

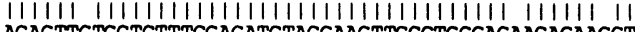
401 ACAGTTGTGCTCTTTCGAGATCTACGAAGTTCCCTGGGAGAACAGAAGGT 450 GlnLeuCysSerPheGluIleTyrGluValProTrpGluAsoArgArgSer

LeuValAsnSerArgCysंGlnGluAlaËnd

451 CCCTGGTGAATTCAAGTGTCAAGAAGCCTAGGGTCTGTGCCAGGCCAG 500 111111111111111111111111111111111111111111 451 CCCTGGTGAAATCAGGTGTCAAGAATCCTAGGGATCTGTGCCAGGCCAT 500 LeuVal LysSerArgCysGlnGluSerEnd

501 TCACACCGACंCACCACCCACंTCCACCCCCं'TGTAGTGCTCंCCACCCCTG 550 1111111111111111111111111111111111111111111111111

501 TCGCACCAGCCACCACCCACTCCCACCCCCTGTAGTGCTCCCACCCCTGG 550

551 ACTGGTGGCCCCCCACCCTGCGGGGAGGCCTCCCCATGTGCC̈TGTGCCAAGA 600 111111111111111111111111111111111111111111111111

551 ACTGGTGGCCCCCACCCTGCGGGAGGCCTCCCCATGTGCCTGCGCCAAGA 600

601 GACAGACAGAGAAGGCTGCÄGGAGTCCTTTGTTGCTCAGCAGGGCGCTCT 650 601 GACAGACAGAGAGGCTGCAGGAGTCCTTGTTGCTCAGCAGGGCGTCT 650

651 GCCCTCCCTC̈CTTCCTTCTTGCTTCTAATAGACCTGGTACATGGTACACA 700 11111111111111111111111111111111111111111111 651 GCCCTCCCTCCTTCCTTCTTGCTTCTCATAGCCCTGGTACATGGTACACA 700

701 CACCCCCACCंТCTGCAATTAAACAGTAGCATCGCC 736

11111111111111111111111111111111111

701 CACCCCCACCTCCTGCAATTAAACAGTAGCATCGCC 736

Fig. 4. Comparison of nucleotide and deduced amino acid sequences of cDNA inserts encoding cystatin $S$ (clone $\mathrm{C} 3$ and $\mathrm{C4}-4$, top lines) and cystatin SN (clone C4-1, bottom lines)

The amino acids in $\mathrm{SN}$ which differ from those of $\mathrm{S}$ are underlined; the EcoRI site in cystatin S (nucleotides 458-463) is underlined once and the polyadenylation sites in both clones are underlined twice. * Indicates the last common nucleotide of clones C4-1 and 10G5.1 (see the text for details).

the mRNAs encoding the other types of salivary cystatin. The seventh clone (C4-4, Fig. 1, lane 8) encoded only the last seven amino acids of a secreted cystatin, as well as the $3^{\prime}$-untranslated 

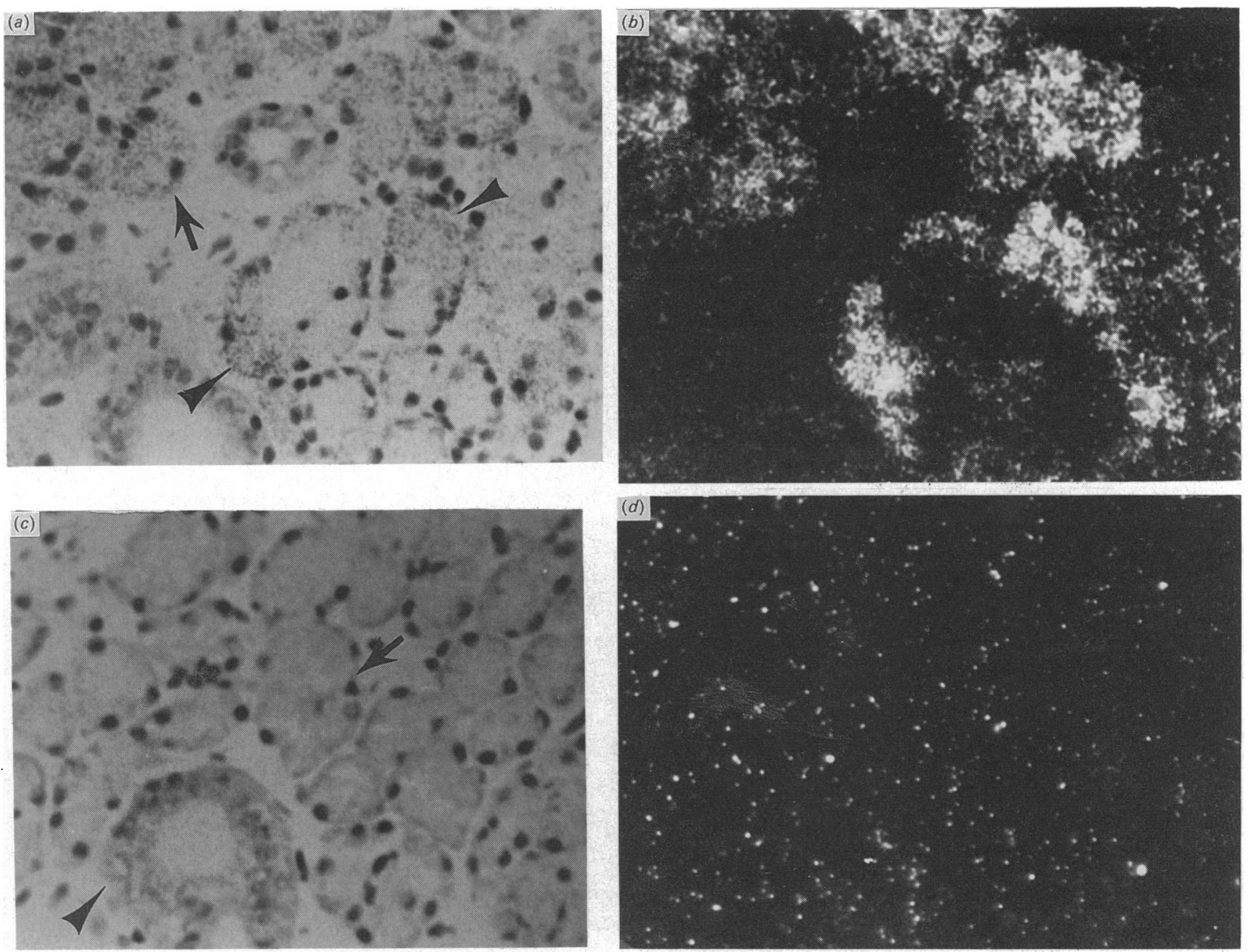

\section{Fig. 5. Hybridization analysis in situ of human SMG}

(a) SMG section hybridized to the anti-sense cRNA probe. A strong signal in the acinar serous cells (arrow) and serous demilunes (arrowhead) was observed (bright-field illumination; magnification $\times 200)$. (b) Dark-field illumination of $(a)$ showing intense hybridization signal in the salivary acini and no signal in the ductal system. (c) SMG section hybridized to the sense cRNA probe; numerous acini (arrow) and an intralobular duct (arrowhead) are shown (bright-field illumination; magnification $\times 200)$. $(d)$ Dark-field illumination of $(c)$, demonstrating only background hybridization.

region (see Figs. 2 and 4). The last amino acid (residue 121) differed from that of cystatin SN (alanine as against serine). This suggested that clone C4-4 encoded either cystatin SA or S and contained an internal EcoRI recognition site and that by subcloning the EcoRI-NotI fragment most of the original insert was lost. The entire insert of the $\lambda$ C4-4 clone was therefore cloned as a SfiI-NotI fragment into the SfiI/NotI sites of the pGem$11 \mathrm{Zf}(+)$ vector and sequenced (see Fig. $2 b$ ). Sequencing data confirmed that the insert of clone C4-4 contained an EcoRI site, that it encoded cystatin $S$ and showed that this was not a fulllength cDNA clone; since it lacked the 5 -untranslated region, the leader peptide region and the first four nucleotides of the secreted peptide. However, it contained the entire $3^{\prime}$-untranslated region, including the polyadenylation signal and the poly(A) tail. To confirm the sequence of the $S f i$ I-EcoRI fragment on the other strand, the SfiI-EcoRI fragment was subcloned into the pGem$11 \mathrm{Zf}(+)$ vector and sequenced (Fig. $2 c)$. The nucleotide sequence of an entire insert of clone (C4-1) encoding cystatin SN was also determined (Fig. 4, lower sequence) and compared with the nucleotide and decoded amino acid sequences of cDNA clones C4-4 and C3, both encoding cystatin S (see below).

\section{Isolation and sequence analysis of a full-length cDNA encoding cystatin $\mathbf{S}$}

The SMG cDNA library was rescreened using the insert of clone C4-4 as the hybridization probe. Twenty positive clones were plaque purified, and several of these (with $\mathrm{C} 4-4$ as a positive control) were used directly for amplification in vitro of DNA by LPCR, thus eliminating the need to isolate $\lambda$ DNA (as described in the Materials and methods section). To determine which inserts of the amplified clones encoded cystatin S (or SA) and which were larger in size than the clone C4-4, the PCR products were digested with $E c o R I$. The undigested and digested DNA was analysed by agarose-gel electrophoresis (Fig. 3, upper panel). Four cDNA inserts out of eight amplified (besides the control C4-4 clone, lane B) contained an EcoRI recognition site and therefore putatively encoded cystatin S or SA. Two of these undigested inserts $(\mathrm{C} 3$, lane $\mathrm{C}$; and $\mathrm{C12}$, lane $\mathrm{M}$ ) were larger than the insert of the C4-4 clone (lane A). To determine whether the $\mathrm{C} 3$ and $\mathrm{C} 12$ inserts were longer at their $5^{\prime}$-end [rather than in their poly(A)+ tail length], a Southern blot of the same gel was probed with a cystatin $5^{\prime}$-end-specific probe (SfiI-EcoRI fragment of the C4-4 insert). The hybridization results, shown 

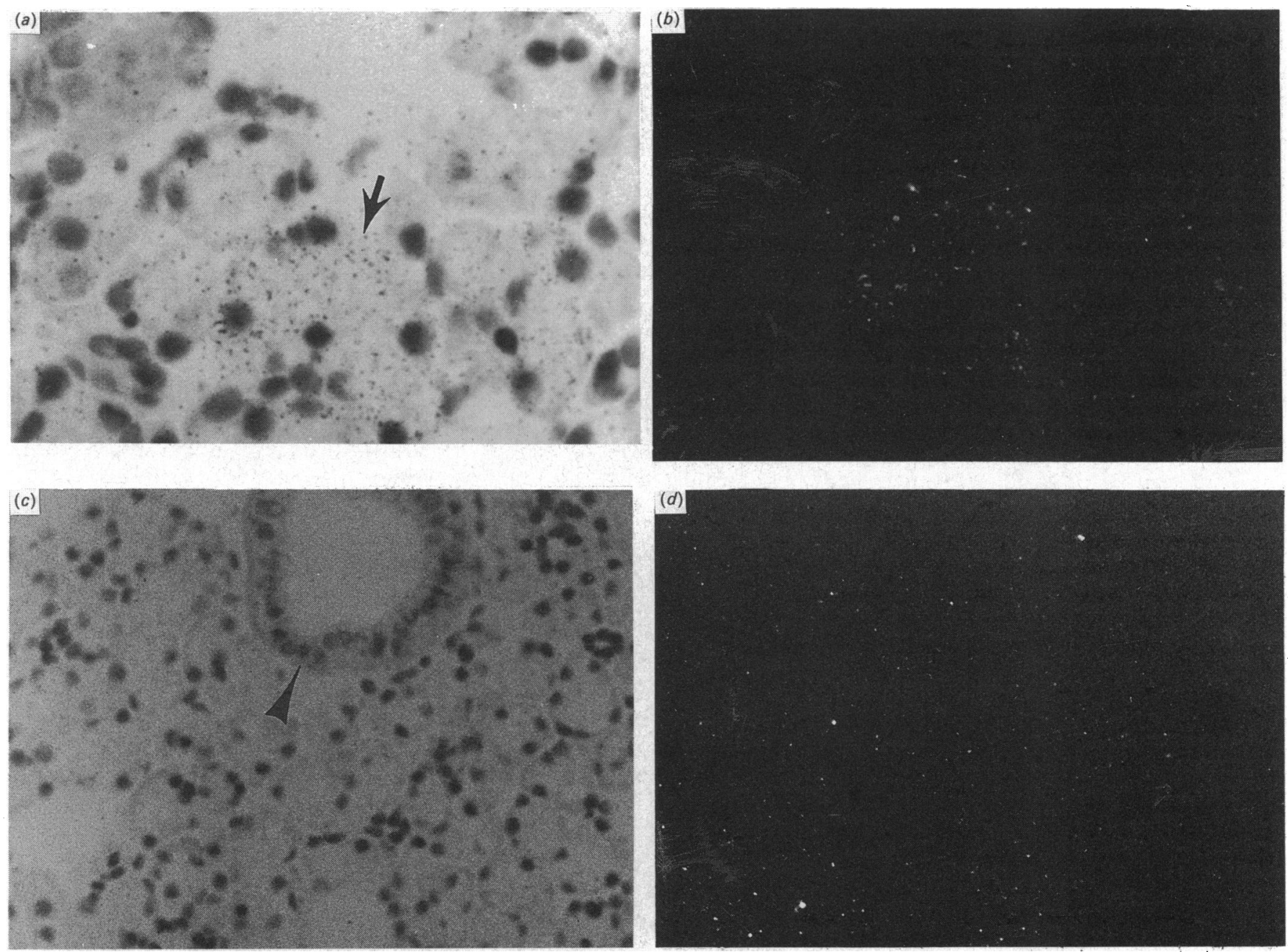

Fig. 6. Hybridization analysis in sitw of human PG

(a) Parotid-gland section hybridized to the anti-sense cRNA probe. A focal scarce deposition of silver grains in the cytoplasm of serous acinar cells (arrow) was observed in the salivary-gland parenchyma (bright-field illumination; haematoxylin/eosin stain; magnification $\times 400)$. (b) Darkfield illumination of $(a)$ to depict the weak hybridization signal observed in the PG tissues. (c) PG section hybridized to the sense cRNA probe, showing an intralobular duct (arrowhead) amid serous acini (bright-field illumination; haematoxylin/eosin stain; original magnification $\times 200$. (d)

Dark-field illumination of $(c)$, showing only background hybridization.

in Fig. 3 (lower panel), confirmed that both C3 (lane D) and C12 (lane N) contained a larger hybridizing fragment than C4-4 (lane B).

Direct sequencing of the double-stranded PCR-amplified cDNA inserts of $\mathrm{C} 3$ and $\mathrm{C} 12$ was performed as described in the Materials and methods section (Kusukawa et al., 1990). Problems associated with direct sequencing of double-stranded DNA generated by PCR can include carry-over of primers and template re-annealing. These were overcome by purification of PCR products on a low-melting agarose, use of a Geneclean Kit (which also removes dNTPs), use of ${ }^{32}$ P-labelled sequencing primers and annealing of primer to template by a snap-cooling procedure. When the termination mixes supplied in the Sequenase kit were used without modification, the sequencing reactions terminated very quickly, resulting in a short sequencing ladder. After increasing the dNTP to ddNTP ratio 3-fold (from 80:1 to $240: 1$ ), the sequencing ladder was readable for about 200 nucleotides (results not shown). Both $\mathrm{C} 3$ and $\mathrm{C12}$ inserts encoded cystatin S. C3 is the same length as C1-1 and C4-1 (which both encode cystatin SN), whereas $\mathrm{C12}$ is 20 bp shorter at its $5^{\prime}$-end. The composite nucleotide sequences and the decoded amino acid sequences of the C3 and C4-4 clones are shown in Fig. 4 (upper sequence), where they are compared with clone C4-1 encoding cystatin SN (lower sequence). Clone $\mathrm{C} 3$ is $736 \mathrm{bp}$ long [excluding the poly(A) tail] and consists of $56 \mathrm{bp}$ of the $5^{\prime}$-untranslated region, followed by $60 \mathrm{bp}$ encoding a putative signal peptide of 20 amino acids, $366 \mathrm{bp}$ encoding the secreted protein of 121 amino acids and the stop codon, and 254 bp of the 3 '-untranslated region containing a polyadenylation signal AATTAAA located $13 \mathrm{bp}$ before the poly(A) tail. The sequence of C4-1, encoding cystatin SN, agrees with the sequence of the clone designated 10G5.1, previously described by Al-Hashimi et al. (1988) with some exceptions. The first 14 nucleotides found at the 5 -end of clone 10G5.1 was not found in any of the clones analysed in the present study, and the sequence of C4-1 loses its similarity to 10G5.1 in the $3^{\prime}$-untranslated region after a nucleotide marked by an asterisk. The 3'-untranslated region of clone C4-1 agrees with that of genomic DNA clone encoding cystatin SN (Saitoh et al., 1987). Therefore the part of the 3 -untranslated region of the clone 10G5.1 may represent a cDNA cloning artefact. The C4-1 clone is also longer than clone 10G5.1; it contains the entire 3 -untranslated region ( 254 bp versus 98 bp in 10G5.1). Three other cystatin clones analysed in the present study have one nucleotide substitution ( $A$ for $G$ ) in a sequence corresponding 
(a)

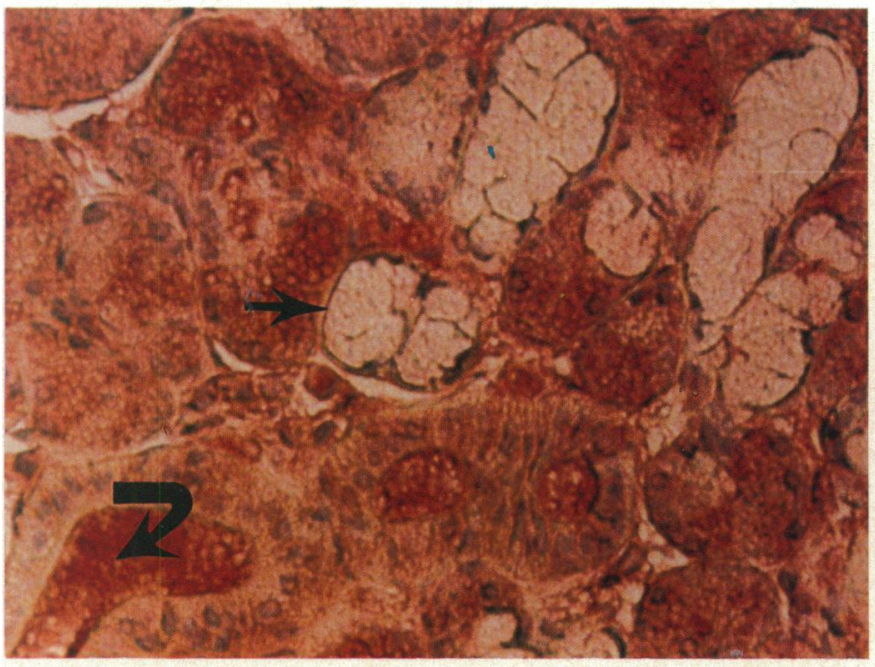

(c)

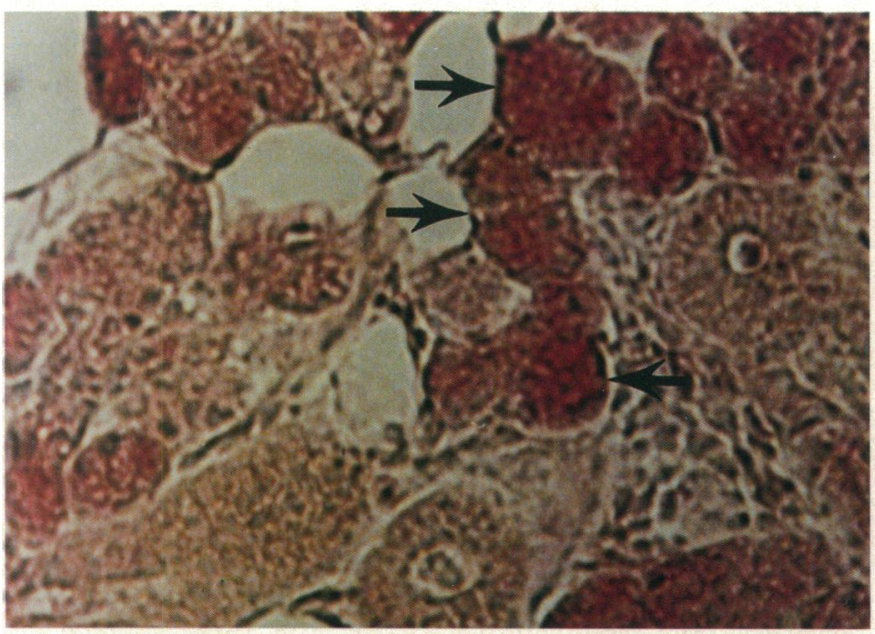

(b)

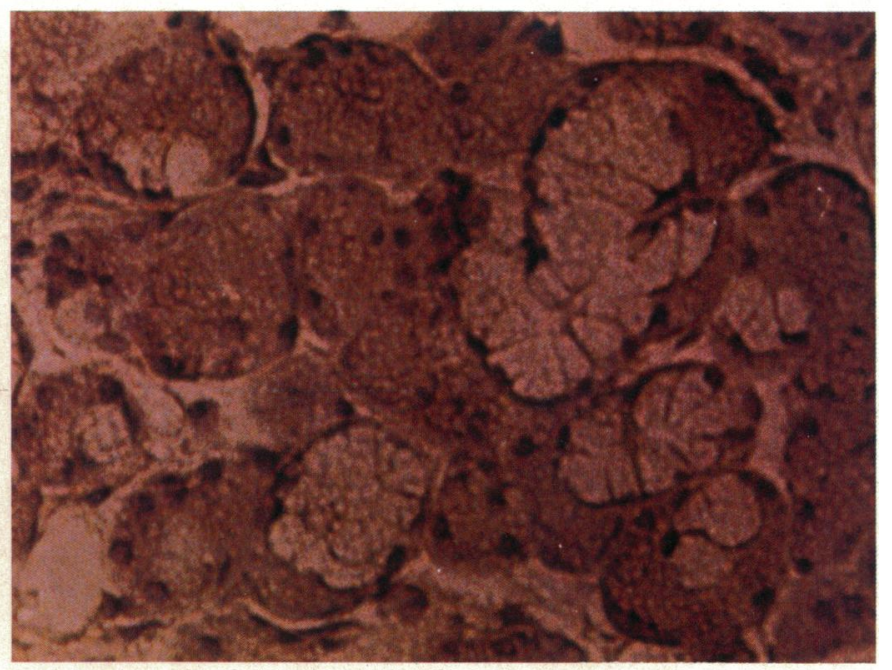

(d)

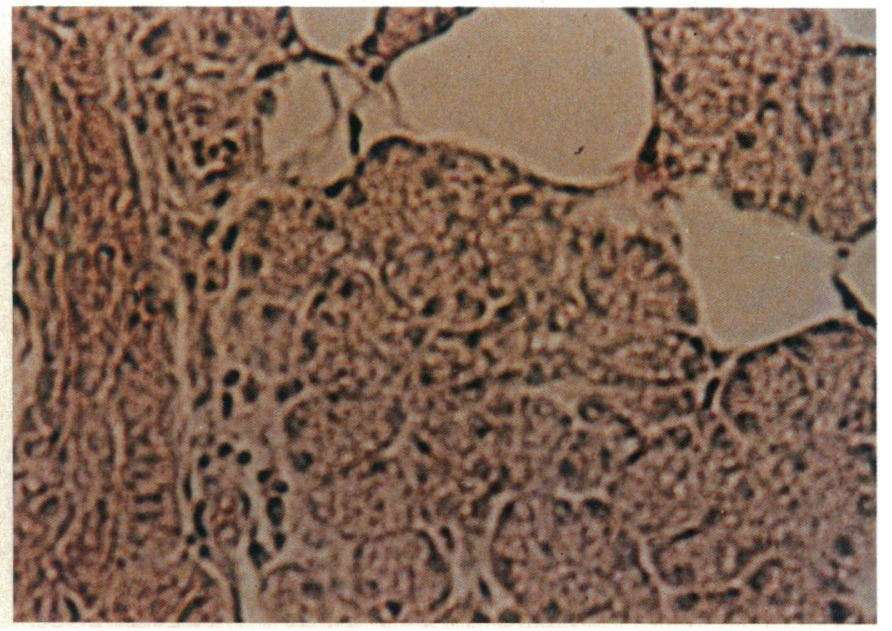

Fig. 7. Immunocytochemistry of human SMG and PG (Mayer's haematoxylin counterstain; magnification $\times 200$ )

(a) SMG tissue section incubated with rabbit anti-cystatin antibody. An intense signal was detected in numerous serous cells and the remaining intraductal saliva (curved arrow). The mucous acini (arrow) were not stained. (b) SMG tissue section incubated with rabbit normal serum (negative control). No signal was detected in the sections examined. (c) PG section incubated with rabbit anti-cystatin antibody. The signal was detected in limited numbers of serous acini (arrows). (d) PG-tissue section incubated with rabbit normal serum (negative control). No signal was observed in the sections examined.

to amino acid 20 of the secreted peptide. This substitution changes asparagine to serine and could represent a genetic variation or an artefact of cDNA synthesis.

\section{Hybridization in situ}

Hybridization in situ to SMG tissue sections demonstrated that the vast majority of serous acinar cells and serous demilunes strongly hybridized with the ${ }^{35} \mathrm{~S}$-labelled anti-sense RNA probe (riboprobe), indicating a high concentration of cystatin mRNA. By contrast, the mucous acini did not express the cystatin genes. Salivary cystatin mRNA was also absent in the intercalated, striated and excretory ductal cells, as well as myoepithelial cells (Figs. $5 a$ and $5 b$ ). Negative controls consisted of tissue sections hybridized with the sense riboprobe (Figs. $5 c$ and $5 d$ ). Similarly, mRNA in serous acinar cells of the PG hybridized to the same probe, whereas no hybridization signal specific for cystatin was observed in parotid ductal and myoepithelial cells (Figs. $6 a$ and $6 b$ ). However, the hybridization signal in parotid tissue was less intense than in the submandibular tissue. Moreover, the signal was not present in all the acinar cells, but only in discrete areas that showed a weak signal, slightly above background. This difference in signal hybridization intensity appears real, since submandibular and parotid tissue sections were run on the same slides, thereby diminishing the likelihood of experimental variation. Again, negative controls consisted of tissue sections hybridized with the sense riboprobe (Fig. $6 c$ and $6 d$ ).

\section{Immunocytochemistry}

The immunocytochemical findings correlated with the results of hybridization in situ. Again, only glandular serous cells gave a detectable signal, whereas the mucous, myoepithelial, and ductal cells (intercalated, striated and excretory) were negative (Fig. 7a). Moreover, there was a stronger signal in the submandibular (Fig. 7a) than in the parotid tissues (Fig. 7c). In addition, different staining characteristics were observed in the tissues examined. The submandibular gland showed a homogeneous and intense staining of the serous cells, whereas the parotid tissue displayed both a focal and less intense staining of 
the serous elements. All the sections incubated with the nonimmune rabbit serum displayed no immunoreactivity (Figs. $7 b$ and $7 d)$.

\section{DISCUSSION}

The cDNA clones $\mathrm{C} 3, \mathrm{C} 12$ and $\mathrm{C} 4-4$ encoding salivary cystatin $\mathrm{S}$ show a high degree of identity with the cystatin $\mathrm{SN}$ cDNA clone C4-1. A high degree of identity was also found with the $3^{\prime}$ terminally truncated cystatin SN cDNA described by Al-Hashimi et al. (1988) and with the genomic clones, CST1 and CST2, encoding cystatin SN and SA respectively (Saitoh et al., 1987). The overall identity between clones C3 (S) and C4-1 (SN) was $94.6 \%$. Interestingly, DNA identity was higher in the $5^{\prime}-(98.2 \%)$ and 3 -untranslated regions $(96.9 \%)$ than in the protein-coding regions $(85.0 \%$ and $93.7 \%$ identities in the leader and secreted peptide regions respectively). Generally, protein-coding regions show higher identities than the flanking regions, owing to the higher selective pressure on the coding sequences. The decoded amino acid sequence of the secreted protein agrees with the sequence of cystatin S determined by Isemura et al. (1984a), except that residue 115 is asparagine rather than aspartic acid. Asparagine is also found in this position in cystatin SA (in both the protein isolated from saliva and decoded amino acid sequence of the genomic clone), whereas lysine is found in cystatin SN. In addition, the DNA sequence of this region in cystatin SA and $S$ contains a distinguishing feature from cystatin SN, namely a recognition site for the restriction enzyme EcoRI.

Since in situ hybridization allows detection and localization of specific nucleic acid sequences directly within a cell or a tissue, the specific mRNAs can be detected in heterogeneous cell populations where only one of multiple sets of cells may be transcribing a particular message (Lum, 1986; Singer et al., 1986). The human SMG contains a mixture of serous and mucous acinar cells, whereas the PG contains just serous cells. Hybridization in situ localized the cystatin mRNA to the serous acinar cells of both SMG and PG, but a much higher concentration of salivary cystatin mRNA was found in the SMG. Higher levels of the salivary cystatin mRNAs in the SMG then in the PG were also found by Sabatini et al. (1989), who studied tissue distribution of cystatin mRNAs in human and macaquemonkey tissues by Northern-blot analyses using a human salivary cystatin partial cDNA clone as a hybridization probe. None of the other tissues they examined showed detectable hybridization signal.

The immunocytochemistry data indicated that the levels of salivary cystatin expression correlated with the amount of salivary cystatin mRNA and also localized the salivary cystatins to the serous cells of the submandibular and parotid glands. These results agree with the immunohistochemical findings of Isemura et al. $(1984 b)$.

Although both salivary cystatins and cystatin $\mathrm{C}$ belong to family 2 of the cystatin superfamily, their expression may be regulated differently. The expression of human salivary cystatins seems to be restricted to salivary tissues with far more mRNA found in SMG than in PG (see above). Cystatin $C$ was expressed in every human tissue examined, including kidney, liver, pancreas, intestine, stomach, lung and placenta with the highest expression seen in seminal vesicles (Abrahamson et al., 1990); human salivary-gland tissues, however, were not examined. The authors postulated that this apparently non-tissue specific expression may be related to the structure of the $5^{\prime}$-flanking region of the cystatin $\mathrm{C}$ gene. In particular, the promoter region lacks a typical CAAT box and contains binding sites (GC-rich elements) for transcription factor $\mathrm{Sp}$ 1, a property associated with the promoter region of 'housekeeping' genes. In contrast, the 5'-flanking regions of cystatin $\mathrm{SN}$ and SA genes lack the Spl binding sites and contain the CAAT box (Saitoh et al., 1987).

In general, an increase in local proteinases and proteinase inhibitors have been observed in the presence of inflammation (Keilova \& Tomasek, 1977; Jarvinen, 1978), acquired immunodefficiency syndrome (Alavaikko et al., 1985) and malignancy (Sloane \& Honn, 1984; Okumichi et al., 1984). In particular, salivary cystatins may participate in modulation of dentalplaque-mediated diseases by inhibiting cysteine proteinases of oral bacterial origin. Indeed, the potential anti-bacterial activity of salivary cystatins was first suggested by Obenauf et al. (1984). Also, Babnik et al. (1988) demonstrated the presence of the three families of cysteine-proteinase inhibitors (kininogens, stefin A, and cystatin C) in inflamed human gingiva. Skaleric et al. (1989) found an inverse correlation between cystatin $\mathrm{C}$ concentration in gingival samples and average pocket depth around the teeth of periodontal patients. Salivary cystatins are involved in the formation of the enamel pellicle acquired in vivo (Levine et al., 1985; Al-Hashimi \& Levine, 1989) and may play a role in mineralization processes (Shomers et al., 1982b; Johnsson et al., 1991). Cystatins are also being investigated as potential anti-viral agents (Korant, 1988; Korant et al., 1988). Earlier studies demonstrated the ability of chicken cystatin to alter intracellular proteolytic processing of poliovirus proteins, resulting in a reduction of virus yield (Korant et al., 1985). Bjorck et al. (1990) also found that a recombinant human cystatin $\mathrm{C}$ displayed strong inhibitory effects on Herpes simplex virus type 1 replication, with no significant effect on poliovirus type 1 .

A complete understanding of the function(s) of human salivary cystatins requires a detailed structural knowledge of these molecules. The availability of the cystatin cDNA clones will facilitate these studies. For example, recombinant salivary cystatins with different structural variations can be used to investigate their diverse biological properties. In fact, we have recently been able to express large amounts of biologically active cystatin SN and S in an E. coli system (Bobek et al., 1990, 1991; L. A. Bobek, X. Wang \& M. J. Levine, unpublished work). Similarly, molecular biological reagents can be used to examine regulatory elements involved in the cystatin gene expression in both normal and diseased salivary tissues.

We thank Dr. Xiahong Wang for help with DNA sequencing, Dr. Craig Jones for his expert assistance with hybridization in situ, $\mathrm{Dr}$. R. E. Cohen for providing salivary-gland tissues and Dr. N. Ramasubbu for help with sequencing-data management. This study was supported in part by U.S. Public Health Service Grants DE07585 and DE08240.

\section{REFERENCES}

Abrahamson, M., Barrett, A. J., Salvesen, G. \& Grubb, A. (1986) J. Biol. Chem. 261, 11282-11289

Abrahamson, M., Olafson, I., Palsdottir, A., Ulvsback, M., LundWall, A., Jensson, O. \& Grubb, A. (1990) Biochem. J. 268, 287-294

Alavaikko, M., Aine, R., Rinne, A., Jarvinen, M., Blanco, G., ApajaSarkkinen, M. \& Hopsu-Havu, V. K. (1985) Int. J. Cancer 35, 319-325 Al-Hashimi, I., Dickinson, D. P. \& Levine, M. J. (1988) J. Biol. Chem. 263, 9381-9387

Al-Hashimi, I. \& Levine, M. J. (1989) Arch. Oral Biol. 34, 289-295

Anastasi, A., Brown, M. A., Kembhavi, A. A., Nicklin, M. J. H., Savers,

C. A., Sunter, D. \& Barrett, A. J. (1983) Biochem. J. 211, 129-138

Babnik, J., Curin, V., Lah, T., Turk, V. \& Skaleric, U. (1988) Biol. Chem. Hoppe-Seyler 369, (Suppl.) 271-276

Barrett, A. J., Fritz, H., Grubb, A., Isemura, S., Jarvinen, M., Katunuma, N., Machleidt, W., Muller-Esterl, W., Sasaki, M. \& Turk, V. (1986a) Biochem. J. 236, 312 
Barrett, A., Rawlings, N., Davies, M., Machleidt, W., Salvesen, G. \& Turk, V. (1986b) in Proteinase Inhibitors (Barrett, A. \& Salvesen, G., eds.), pp. 515-569, Elsevier, Amsterdam

Bjorck, L., Grubb, A. \& Kjellen, L. (1990) J. Virol. 64, 941-943

Bobek, L., Wang, X., Bobek, M. \& Levine, M. J. (1990) J. Dent. Res. 69, (Special Issue) 168 (abstr. 468)

Bobek, L. A., Wang, X. \& Levine, M. J. (1991) J. Dent. Res. 70 (Special Issue) 500 (abstr. 1876)

Bode, W., Engh, R., Musil, D., Thiele, U., Huber, R., Karshikov, A., Brzin, J., Kos, J. \& Turk, V. (1988) EMBO J. 7, 2593-2599

Brzin, J., Popovic, T., Turk, V., Borchart, U. \& Machleidt, W. (1984) Biochem. Biophys. Res. Commun. 118, 103-109

Devereux, P., Haeberli, P. \& Smithies, O. (1984) Nucleic Acids Res. 12 387-391

Ghiso, J., Jensson, O., \& Frangione, B. (1986) Proc. Natl. Acad. Sci. U.S.A. 83, 2974-2978

Grubb, A. \& Lofberg, H. (1982) Proc. Natl. Acad. Sci. U.S.A. 79, 3024-3027

Hawke, D. H., Yuan, P. M., Wilson, K. J. \& Hunkapiller, M. W. (1987) Biochem. Biophys. Res. Commun. 145, 1248-1253

Isemura, S., Saitoh, E. \& Sanada, K. (1984a) J. Biochem. (Tokyo) 96 489-498

Isemura, S., Saitoh, E., Ito, S., Isemura, M. \& Sanada, K. (1984b) J. Biochem. 96, 1311-1314

Isemura, S., Saitoh, E. \& Sanada, K. (1986) FEBS Lett. 198, 145-149

Isemura, S., Saitoh, E. \& Sanada, K. (1987) J. Biochem. (Tokyo) 102, 693-704

Jarvinen, M. (1978) J. Invest. Dermatol. 71, 114-118

Johnsson, M., Richardson, C. F., Campbell, A. A., Bergey, E. J., Levine, M. J. \& Nancollas, G. H. (1991) Arch. Oral Biol., in the press

Keilova, H. \& Tomasek, V. (1977) Acta Biol. Med. Ger. 36, 1873-1881

Korant, B. (1988) CRC Crit. Rev. Biotechnol. 8, 149

Korant, B., Brzin, J. \& Turk, V. (1985) Biochem. Biophys. Res. Commun. 127, 1072-1076

Korant, B., Towatari, T., Kelley, M., Brzin, J., Lenarcic, B. \& Turk, V. (1988) Biol. Chem. Hoppe-Seyler (Suppl.) 369, 281-286

Kusukawa, N., Uemori, T., Asada, K. \& Kato, I. (1990) BioTechniques 9, 66-72

Received 4 February 1991/19 March 1991; accepted 28 March 1991
Levine, M. J., Tabak, L. A., Reddy, M. \& Mandel, I. D. (1985) in Molecular Basis of Oral Microbial Adhesion (Mergenhagen, S. \& Rosan, B., eds.), pp. 125, American Society of Microbiologists, Washington

Lum, J. B. (1986) BioTechniques 4, 32-39

Messing, J. (1983) Methods Enzymol. 101, 20-78

Muller-Esterl, W., Iwanaga, S. \& Takanishi, S. (1986) Trends Biochem. Sci. 11, 336-339

Needleman, S. B. \& Wunsh, C. (1970) J. Mol. Biol. 48, 443-453

Obenauf, S. D., Fisher, R. H., Cowman, R. A. \& Fitzgerald, R. J. (1984) Infect. Immun. 46, 797-801

Okumichi, T., Nishiki, M., Takasugi, S., Yamane, M. \& Ezaki, H. (1984)

Hiroshima J. Med. Sci. 33, 801

Rawlings, N. D. \& Barrett, A. J. (1990) J. Mol. Evol. 30, 60-71

Sabatini, L. M., Warner, T. F., Saitoh, E. \& Azen, E. A. (1989) J. Dent. Res. 68, 1138-1145

Saitoh, E., Kim, H.-S., Smithies, O. \& Maeda, N. (1987) Gene 6, 329338

Saitoh, E., Isemura, S., Sanada, K., Kim, H.-S., Smithies, O. \& Maeda, N. (1988) Biol. Chem. Hoppe-Seyler 369 (Suppl.), 191-197

Sambrook, J., Fritsch, E. \& Maniatis, T. (1989) Molecular Cloning, a Laboratory Manual (2nd edn.), Cold Spring Harbor Laboratory Press, Cold Spring Harbor, NY

Sanger, F., Nicklen, S. \& Coulson, A. (1977) Proc. Natl. Acad. Sci. U.S.A. 74, 5463-5467

Shomers, J. P., Tabak, L. A., Levine, M. J., Mandel, I. D. \& Ellison, S. A. (1982a) J. Dent. Res. 61, 973-977

Shomers, J. P., Tabak, L. A., Levine, M. J., Mandel, I. D. \& Hay, D. I. (1982b) J. Dent. Res. 61, 397-399

Singer, R. B., Bentley-Lawrence, J. \& Villnave, C. (1986) BioTechniques $4,230-250$

Skaleric, V., Babnik, J., Curin, V., Lah, T. \& Turk, V. (1989) Arch. Oral Biol. 34, 301-305

Sloane, B. F. \& Honn, K. V. (1984) Cancer Mets. Rev. 3, 249-263

Smith, D. P., Johnstone, E. M., Little, S. P. \& Hsiung, H. M. (1990) BioTechniques 9, 48-54

Young, R. A. \& Davis, R. W. (1983) Proc. Natl. Acad. Sci. U.S.A. 80, 1194-1198 